\title{
A Igreja no contexto da dádiva do Espírito e como sinal escatológico do reino de Deus: estudo sobre a vida, a obra e dois tópicos eclesiológicos da Teologia Sistemática de Wolfhart Pannenberg
}

\author{
Orientadora: Maria Teresa de Freitas Cardoso \\ Mestrando: Andriê Luiz Felipe \\ Área de Concentração: Teologia Sistemático-Pastoral \\ Linha de Pesquisa: Religião e Modernidade
}

Wolfhart Pannenberg é considerado um dos mais importantes teólogos do século XX. Nesta dissertação estudamos como Pannenberg viu a Igreja no contexto da dádiva do Espírito e como sinal escatológico do reino de Deus. O percurso que realizamos para o estudo foi: apresentar primeiro um resumo da vida e da obra de Pannenberg; depois, os elementos gerais de sua teologia, a explicação do autor sobre a necessidade da teologia sistemática na sociedade secularista moderna e algumas observações sobre o lugar da eclesiologia. Por fim, debruçamo-nos sobre o objeto principal desta dissertação, ou seja, os dois tópicos acima indicados, que estão no início do terceiro volume da obra Teologia Sistemática. Nesses dois tópicos observamos que, para Pannenberg, a Igreja está diretamente relacionada com o Espírito Santo, já que a Igreja só é sinal do reinado vindouro de Deus porque recebe a atuação do Espírito como dádiva escatológica. Vimos que a Igreja se diferencia do reino de Deus, porque ela é apenas sinal e por isso é antecipação e não o próprio reino de Deus. Para Pannenberg, a Igreja é o corpo de Jesus Cristo e assim é representação do mistério da salvação. Concluímos também que o pensamento teológico de 
Pannenberg colaborou para o diálogo da Igreja com a sociedade moderna e é um pensamento que ainda tem muito a contribuir na atualidade. Por isso, o estudo da sua eclesiologia é relevante para a realização de uma pastoral conexa à realidade concreta dos seres humanos.

Palavras-chave: Wolfhart Pannenberg. Ecclesiology. Spirit. 